УДК 37.02

DOI:

Галина Колесник, викладач кафедри іноземних мов Національного університету “Львівська політехніка"

\title{
ВПЛИВ ЕМОЦІЙ НА КОГНІТИВНІ ПРОЦЕСИ ПІД ЧАС ВИВЧЕННЯ ІНОЗЕМНОЇ МОВИ СТУДЕНТАМИ ПЕРШОГО КУРСУ НАВЧАННЯ
}

Стаття присвячена дослідженню взаємовпливу емоиійних та когнітивних процесів. Особливу увагу автор звертає на роль емоційного стану під час вивчення іноземної мови студентами першого року навчання. У статті визначаються ключові функиії емочій в пізнавальній діяльності. Автор припускає, ицо надмірні емоиійні переживання викликають суттєві зміни в когнітивних проиесах $і$ мають дезорганізуючий вплив. Враховуючи всі аспекти питання, автор пропонує стратегію щзодо подолання надмірної схвильованості, регулячії емочій та успішного формування мовленнєвої компетенції у студентів під час вивчення іноземної мови.

Ключові слова: когнітивний процеес; емоції; мовленнєва компетенція; регуляція поведінки; спілкування.

Jim. 14.

Halyna Kolesnyk, Lecturer of the English Department Lviv Polytechnic National University

\section{THE INFLUENCE OF EMOTIONS ON COGNITIVE PROCESSES WHILE STUDYING FOREIGN LANGUAGES BY THE FIRST-YEAR STUDENTS}

Affect and cognition are known to be highly interdependent processes which denote the person perception of the environment. Emotions accompany any human activity, direct cognitive processes, form a personality. However, a high degree of emotional experience that is not controlled by human consciousness causes partial or complete disorganization. It may harm to mental activity and declines ability to adequately perceive information and make decisions. So, we aimed to investigate the influence of affect on cognitive processes of students while studying foreign languages. Firstly, we determined two key functions of emotions: informative and motivative. It allowed us to suggest that a main motive of any human activity is to obtain pleasant emotions and avoid negative one. Therefore, it can be assumed that human behavior is governed by the will to achieve this state. Then we tried to discuss several instances of how affect influences cognition. It was studied out that hyperintensive emotions may cause significant changes in cognitive processes and have destroying force.

Excessive emotional excitement can help accomplish simple tasks and block the ability to perform more complex one. Based on the results of the emotional phenomena investigation we could prove that successful mastering of foreign language depends on the emotional state of the student, because mood can affect attention, memory and perception of information. There is general agreement that anxious individuals show the worse results in cognitive processes. On the other hand, positive mood might increase the visual scope of attention, improve memorization and have effect on intrinsic motivation. Thus, the strategy for overcoming excessive nervousness and emotion regulation while studying foreign languages was proposed in this paper.

Keywords: cognitive process; emotion; language proficiency; emotion regulation; communication.

П остановка проблеми. Прискорений темп життя сучасної молоді, жорстка конкуренція на ринкупраці, прагнення до соціального престижу, пошук власних життєвих перспектив, а також шквал різноманітної інформації є тими факторами, які утримують людину у стані стресу. Інтенсивні емоційні навантаження призводять до нервових розладів, перешкоджають раціональному мисленню. Але емоції супроводжують будь-яку діяльність людини, у тому числі і пізнавальну. Навчання через переживання буває більш продуктивним, ніж примусове засвоєння певних фактів. Ми емоційно реагуємо на отримані знання, відчуваючи задоволення або незадоволення, хвилювання або зацікавленість. Саме емоції спонукають нас до подальших дій.

Отже, інтелектуальні та емоційні процеси $\epsilon$ взаємопов'язаними складовими діяльності людини. Актуальним питанням психології та педагогіки є вирішення проблеми взаємодії когнітивних та емоційних процесів, встановлення їх деструктивного або конструктивного ефекту. Які емоції мотивують до пізнання, а які блокують пізнавальні процеси? Які конструктивні стратегії використовувати для зниження інтенсивності негативних переживань? Чи здатний афект спотворювати сприйняття інформації? 


\section{ВПЛИВ ЕМОЦЙ НА КОГНІТИВНІ ПРОЦЕСИ ПІД ЧАС ВИВЧЕННЯ}

ІНОЗЕМНОЇ МОВИ СТУДЕНТАМИ ПЕРШОГО КУРСУ НАВЧАННЯ

Оскільки в умовах процесу глобалізації, який не оминув і Україну, від фахівців вимагається володіння іноземною мовою, найбільшої уваги заслуговує дослідження взаємодії емоційних та когнітивних процесів в навчальній діяльності, а саме під час вивчення іноземної мови студентами першого року навчання, що допоможе виявити найбільш продуктивні методи навчання.

Аналіз останніх публікацій. Вплив емоцій на когнітивні процеси цікавив багатьох дослідників. Місце емоцій в процесі пізнання вивчали ще давньогрецькі філософи Платон і Аристотель. Розвиваючи положення Сократа і Платона, Аристотель стверджував, що не може бути вільною людина, яка живе емоціями. Свобода можлива за умови розумної регуляції поведінки. На його думку, емоції можуть бути усвідомлені розумом і тому не шкодять процесу пізнання, надаючи нашим розумним діям лише емоційний контекст. У той же час надмірні негативні емоції, афект, мало піддаються раціональному усвідомленню, призводять до спонтанної поведінки, а тому є руйнівними для людини [12].

Але початок вивчення питання про роль емоцій в когнітивному процесі поклав французький психіатр П'єр Жане, розглядаючи емоції як реакцію людини на свої вчинки, у тому числі і інтелектуальні [4]. Інший видатний французький психолог Теодюль Рибо розрізняв когнітивні та емоційні процеси, доводячи, що інтелектуальна діяльність не терпить емоційних домішок, які стають причиною нелогічності [7]. Вперше на тісний зв' язок емоційної та когнітивної сфери вказав голландський філософ Б. Спіноза (1632 - 1677). На його думку, ми не тільки переживаємо емоції, але й можемо визначати їх походження, отже підкоряти їх розуму [11].

Л.С. Виготський відзначав єдність і взаємовплив когнітивних і емоційних процесів "Хто відірвав мислення 3 самого початку від афекту, той назавжди закрив собі шлях до пояснення причин самого мислення” [2,92]. Ідею єдності емоційного і раціонального підтримував С.Л. Рубінштейн, наголошуючи, що емоції підсилюють інтелектуальну діяльність, але гіперінтенсивне емоційне збудження (афект) викликає непередбачувану, неконтрольовану поведінку, як наслідок, гальмуючи пізнавальну функцію [10]. На думку американського психолога Р.У. Ліпера, емоційні процеси керують нашими думками і визначають сприйняття інформації [9, 147]. Д.А. Леонтьєв, російський психолог, автор концепції саморегуляції, жартома зазначає, що “інтелект афекту не товариш” [6]. Взаємодію когнітивних та афективних процесів вивчав А.В. Брушлинський, стверджуючи, що емоції можуть як сприяти, так і запобігати мисленню [1]. В.К. Вілюнас доводить неможливість існування емоцій окремо від пізнавальних процесів, обгрунтовуючи це тим, що емоції виконують мотивуючи та оцінюючи функції, спонукаючи до певної дії [3, 82].

Американський лінгвіст, доктор Стефан Крашен провівши багато досліджень щодо ролі нелінгвістичних факторів у процесі засвоєння другої мови на початковому етапі, запропонував гіпотезу емоційного фільтра. Лише позитивні фактори - мотивація, впевненість в своїх силах, інтерес, ентузіазм - гарантують успішне оволодіння мовою [14].

Отже, незважаючи на те, що проблемі взаємозв'язку емоційної та когнітивної сфери присвячено чимало праць, питання впливу емоцій на пізнавальну діяльність під час вивчення іноземної мови вивчено недостатньо.

Метою статті $є$ дослідження впливу емоцій на пізнавальну діяльність студентів під час вивчення іноземної мови і як слідство розробка стратегії конструктивного використання емоцій для регуляції процесу пізнання.

Виклад основного матеріалу. Класичне визначення трактує емоції як реакцію суб'єкта на діючий подразник або на результат власних дій. Емоції супроводжують будь-яку діяльність людини. С.Л. Рубінштейн відзначав, що продуктивність та результативність різних видів діяльності людини залежить від рівня розвитку здібностей його емоційного плану, пов'язаних 3 визначенням свого власного внутрішнього стану та емоційним станом оточення [10].

Відзначають дві ключові функції емоцій: інформаційну і мотивуючу [13]. Суть інформаційної функції емоцій полягає в тому, щоб забезпечувати процеси мислення і приймати рішення. Емоції впливають на то, яка інформація надходить в розпорядження процесів оцінки i прийняття рішення. Тому емоційне переживання вже є самостійним матеріалом для процесу мислення. Так, окремі емоції здатні викликати відповідні ефекти: радість продукує більш позитивне сприйняття i оцінку, ніж у нейтральному стані, смуток призводить до негативного оцінювання, гнів та страх призводять до часткової або повної втрати контролю над своїми діями.

Мотиваційна функція емоцій проявляється в їх адаптивному впливі на мотиви поведінки людини. Ключовим мотивом будь-якої діяльності $\epsilon$ отримання приємних емоцій і запобігання неприємних. Тому, відштовхуючись від 


\section{ВПЛИВ ЕМОЦІЙ НА КОГНІТИВНІ ПРОЦЕСИ ПІД ЧАС ВИВЧЕННЯ}

ІНОЗЕМНОЇ МОВИ СТУДЕНТАМИ ПЕРШОГО КУРСУ НАВЧАННЯ

зворотного, можна стверджувати, що прагнення цих емоцій і обумовлює поведінку людини.

Емоції виступають мотиватором, спонукаючи до будь-якої діяльності, у тому числі і пізнавальної. Під впливом емоцій може змінюватися протікання пізнавальних процесів, обумовлене поведінкою суб'єкта. Людині, яка знаходиться в емоційно нейтральному стані, або переживає емоції помірної інтенсивності, притаманно зважувати всі обставини i мотиви. Будь-яка діяльність починається із свідомої емоційної оцінки, і в самому процесі домінує здоровий розум. У той же час, якщо дії суб'єкта зумовлені лише холодним мисленням, без емоційного забарвлення, вони $є$ значно менш успішними, ніж ті, що супроводжуються емоційно.

Емоції високого ступеню інтенсивності, як негативні, так і позитивні, здатні спотворювати сприйняття інформації, викликати суттєві зміни в пізнавальних процесах і мати дезорганізуючу, деструктивну властивість. В стані підвищеного інтересу або емоційного збудження людина може бути настільки захопленою, що виявляється нездатною адекватно сприймати інформацію та вирішувати поставлені задачі. Проте, позитивні емоції, пов'язані з досягненням успіху, зазвичай сприяють діяльності. У той же час, коли успіх досягається тяжкою працею, фізичним та емоційним виснаженням, спостерігається пригнічення когнітивних процесів.

Надмірне емоційне збудження може сприяти виконанню нескладних завдань і блокувати можливість виконання більш складних. Виникає ситуація порочного емоційного кола, коли зміст інформаційного матеріалу посилює емоцію, а емоція, у свою чергу, зациклює на інформаційномузмісті, який викликав цю емоцію. Тому не завжди вдається подолати сильні емоції шляхом раціонального впливу, доцільніше загасити емоції, які перешкоджають успішному когнітивному процесу, новими емоційними спалахами, що сприятимуть пізнавальній діяльності.

Подібний феномен пояснюється тим, що емоційний стан тісно пов'язаний з різними фізіологічними процесами (гормональними, вегетативними), які впливають на фізичне самопочуття людини (ритм роботи серця, артеріальний тиск, рівень цукру в крові тощо) тим самим зашкоджуючи або сприяючи когнітивним процесам. Також особистість 3 низьким рівнем емоційного інтелекту, тобто здатністю керувати своїм емоційним станом, більш зазнає впливу емоцій на пізнавальну діяльність. Саме тому пізнавальні процеси у дітей та підлітків більш залежать від емоційного стану, ніж у дорослої людини. У педагогічний практиці неодноразово доводилося відзначати, що інколи студенти 3 нищим рівнем знань але здатні регулювати свій емоційний стан, на тестах демонстрували результати кращі, ніж ті студенти, чиї знання були затьмарені надмірним переживанням. Іншою характеристикою, що впливає на взаємозв'язок емоційних і когнітивних процесів є самооцінка особистості. Е.Л. Носенко проведені дослідження, на підставі яких було встановлено, що маючи однаковий рівень інтелекту та підготовки, студенти 3 низькою самооцінкою менш успішно справлялися 3 інтелектуальними завданнями, ніж студенти 3 високою самооцінкою. Автор доводить, що психологічним механізмом впливу самооцінки на ефективність інтелектуальної діяльності є емоційний стан особистості [8].

Як було зазначено вище, будь яка пізнавальна діяльність супроводжується емоційними переживаннями, і в першу чергу це стосується процесу оволодіння іноземною мовою. Свідоме вивчення іноземної мови часто припадає саме на студентський етап життя особистості, коли поставлені певні ціли, визначаються соціальні та моральні моделі. Цей етап розвитку людини є дуже важливим і складним, бо відбувається стрімкий перехід від дитинства до дорослого життя. Період адаптації першокурсника може бути ускладнений як зовнішніми (оточення, матеріально-технічне забезпечення, рівень педагогічної майстерності викладачів тощо) так і внутрішніми факторами (інтелект, мотивація, адаптаційний потенціал, емоційний розвиток). Студенти переживають надмірну схвильованість, яка пояснюється зміною статусу, інакшим оточенням, розгубленістю перед вимушеною самоорганізацією. Отже, від викладача вимагається підвищена увага до першокурсника, диференційний психолого-педагогічний підхід, вибір методів, більш сприятливих для формування інтересу до пізнавальної діяльності. Вивчення іноземної мови для багатьох пов'язано з відчуттям страху, нерозуміння, виснажливого заучування. Дійсно, вивчення іноземної мови якоюсь мірою $є$ стресом. Як зазначив А.Ф. Качанов, “Під час вивчення іноземної мови необхідно переналаштовуватися на інший пласт мовного універсуму, використовувати і будувати раніше не існуючи асоціативні зв'язки, залучати мнімотехніки, розвивати і вдосконалювати вимову, активізовувати комунікативні навички, через які презентується сама думка людини" [5]. Перелічені фактори здатні негативно впливати на 
успішність оволодіння всіма чотирма аспектами мови: читання, письмо, слухання, говоріння. Завдання викладача позбавити студентів емоційного напруження під час вивчення іноземної мови, перетворити заняття на джерело отримання натхнення і задоволення. Можна почати заняття традиційно 3 перевірки присутності студентів, перевірки домашнього завдання, ознайомленням з планом заняття, тобто відразу налаштовуючи студентів на класичне вивчення матеріалу, яке ще й викликає спогади про невдалі спроби вивчення мови у школі. Бачимо результат - схилені голови, понурені очі, гортання сторінок підручника і поглядання на годинник. За іншим сценарієм заняття починаємо у жартівливій формі, розкуто, не фокусуючи думки студентів на складних граматичних таблицях, тестах і оцінках.

Для подолання труднощів оволодіння навичками читання, писання, слухання та говоріння, пов'язаних $з$ емоційною напругою, викладач має розробити конструктивні стратегії, враховуючи задачі, цілі, моральні цінності, професійне становлення студентів.

Ми пропонуємо наступну стратегію для запобігання немотивованого хвилювання у студентів під час формування мовленнєвої компетенції на заняттях з іноземної мови:

- максимально знизити тривожність кожного окремого студента і створити атмосферу невимушеного спілкування, яка дозволить почуватися природньо. Важливо, що на цьому етапі істотно змінюється роль викладача від диктатора до фасилітатора. Викладач створює ситуації, які спонукають до спілкування і стає його рівноправним учасником;

- зорієнтувати студентів на успіх. Сприйняття на слух одного матеріалу студентами з однаковим рівнем володіння мовою більш успішно відбувається угрупах, де перед прослуховуванням викладач програмує студентів на відмінний результат, підносячи їх здібності та применшуючи реальний рівень складності завдання;

- враховувати практичне значення матеріалу, призначеного для аудіювання, перекладу або обговорення. Студент прагне отримати знання, які він зможе застосовувати в своїй професійній діяльності. Отже, емоції, спричинені цікавою інформацією професійного характеру, нівелюють немотивоване хвилювання;

- заохочувати прагнення покращувати результати, підвищувати самооцінку. 3 цією метою після аудитивного матеріалу, який викликав істотні труднощі сприйняття, пригнічуючи самооцінку студентів, пропонуємо прослухати апріорі доступний фабульний текст, який на контрасті підбадьорить студентів, спонукаючи до подальшого вдосконалення знань. Чередувати тексти для читання та перекладу за рівнем складності, залежно від емоційного стану студентів;

- уникати критики невдач. Всім зауваженням мають передувати компліменти, які вказують на досягнення в оволодінні навичками читання, письма, слухання, говоріння. Таким чином, перед виконанням наступного завдання нам вдасться уникнути домінування страху і низької самооцінки.

Висновки. Отже, сила впливу емоцій на пізнавальний процес незаперечна. Позитивні емоції сприяють активізації пізнавальних процесів, розвивають евристичне мислення, схиляють студентів до гармонійної співпраці. У той час, як негативний афект викликає оборонну реакцію, блокуючи адекватне сприйняття інформації. Під час вивчення іноземної мови для врегулювання емоційного навантаження та досягнення поставлених цілей доцільно враховувати нелінгвістичні фактори. Задача викладача вмілими діями скорегувати немотивовану надмірну схвильованість і скерувати емоції в конструктивне русло продуктивної інтелектуальної діяльності.

Перспективи подальших досліджень вбачаємо у розробці стратегій щодо розвитку у студентів емоційної сфери і формування емоційного інтелекту для забезпечення оптимізації когнітивних процесів.

\section{ЛІТЕРАТУРА}

1. Брушлинский А.В. Психология субъекта в изменяющемся обществе /А.В. Брушлинський// Психол. журн. - 1997. - Т.18. № 2. - С. 18-32.

2. Виготский Л.С. Собрание сочинений: в 6 т. - M.: 1982. - T. 2. - 504 c.

3. Вилюнас В.К. Психология эмоциональных явлений. - М.: Изд-во Моск. ун-та, 1976. - 142 с.

4. Жане П'єр. Психологическая эволюция личности. - М.: Академический проект, 2010. 399 c.

5. Качанов А.Ф. Влияние эмоционального интеллекта на изучение иностранных языков у подростков. - Северо-Кавказский психологический вестник, № 10/4. 2012. - С. 25-27.

6. Леонтьєв Д.А. Однопсишия//Флогистон [Електронний ресурс] - режим доступу: http// flogiston.ru/articles/humor/.

7. Лялина Я.И. Исследование эмоциональноаффективной сферы личности в трудах Теодюля Рибо [Текст] // Современная психология: 
материалы II Междунар. науч. конф. (г. Пермь, июль 2014 г.). - Пермь: Меркурий, 2014. - С. 1-6. - Режим доступу: https://moluch.ru/conf/psy/ archive/111/6001/ (дата звернення: 16.02.2018).

8. Носенко Е.Л., Коврига Н.В. Емоційний інтелект: концептуалізація феномену, основні функції. Монографія. - Київ, 2003. - С. 159.

9. Психология эмоций. Тексты/ Под ред. В.К.Вилюнаса, Ю.Б.Гиппенрейтер. - М.: Изд-во Моск. ун-та, 1984. - 288 с.

10. Рубінштейн С.Л. Проблеми загальної психології. - М.: Педагогіка, 1973. - 423 с.

11. Спиноза Б. Избранные произведения. - Т.1. - M.:1957.- $631 \mathrm{c.}$

12. Спіркін А.Г. Філософія: Підручник. - 2-е видання. - М.: Гардаріки, 2004. - С. 59-66.

13. Frijda, N.H. (1994). Emotions are functional, most of the time. In P. Ekman \& R. J. Davidson (Eds.), The nature of emotion (pp. 112-136). NY: Oxford University Press

14. Krashen, S.D. Principles and Practice in Second Language Acquisition. - Pergamon, 1982.

\section{REFERENCE}

1. Brushlynskyi, A.V. (1997). Psihologiya sub'ekta v izmenyayushchemsya obshchestve [The psychology of the subject in a changing society]. Psyihological Journal, vol.18, no.2, pp. 18-32. [in Russian].

2. Vigotskij, L.S. (1982). Sobranie sochinenij v $6 t$. [Collected works in 6 volumes]. Moscow, vol. 2, 504 p. [in Russian].

3. Vilyunas, V.K. (1976). Psihologiya ehmocionalnyh yavlenij [Psychology of emotional phenomena]. Moscow: MGU Publ., 142 p. [in Russian].

4. Zhane Per (2010). Psihologicheskaya ehvolyuciya lichnosti [Psychological evolution of personality]. Moscow: Akademicheskij proekt, 339 p. [in Russian].

5. Kachanov, A.F. (2012). Vliyanie ehmocionalnogo intellekta na izuchenie inostrannyh yazykov u podrostkov [The influence of emotional intelligence on the study of foreign languages in adolescents].
North Caucasian Psychological Bulletin, no.10(4), pp. 25-27. [in Russian].

6. Leontev, D.A. (1997). Odnopsishiya. Flogiston [Electronic resource]. Available at: http//flogiston.ru/ articles/humor/ (accessed 4 February 2018). The name of the screen. [in Russian].

7. Lyalina, Ya. I. (2014). Issledovanie ehmocionalno-affektivnoj sfery lichnosti $\mathrm{v}$ trudah Teodyulya Ribo [Investigation of the emotionalaffective sphere of the personality in the writings of Theodule Ribot]. Sovremennaya psihologiya: materialy II Mezhdunar. nauch. konf. - Modern psychology: Proceedings of the 2nd Scientific Conference. Perm: Merkurij, pp. 1-6. Available at: https://moluch.ru/conf/psy/archive/111/6001/ (accessed 16 February 2018). The name of the screen. [in Russian].

8. Nosenko, E.L. \& Kovriga, N.V. (2003). Emocijnij intelekt: konceptualizaciya fenomenu, osnovni funkcii [Emotional intelligence: the conceptualization of the phenomenon, the main functions]. Kyiv, 159 p. [in Ukrainian].

9. Vilyunasa, V.K. \& Gippenreiter, Yu.B. (1984). Psihologiya ehmocii. Teksty [Psychology of emotions. Texts]. Moscow: MGU Publ., 288 p. [in Russian].

10. Rubinshtein S.L. (1973). Problemy zahalnoi psykholohii [Problems of general psychology]. Moscow: Pedahohika, 423 p. [in Ukrainian].

11. Spinoza, B. (1957). Izbrannye proizvedeniya [Selected works]. Moscow, vol.1, 631 p. [in Russian]. 12. Spirkin, A. H. (2004). Filosofiya [Philosophy]. Textbook, issue 2. Moscow: Hardariky, pp. 59-66. [in Ukrainian].

13. Frijda, N. H. (1994). Emotions are functional, most of the time. In P. Ekman \& R. J. Davidson (Eds.), The nature of emotion (pp. 112-136). NY: Oxford University Press [in English].

14. Krashen, S.D. (1982). Principles and Practice in Second Language Acquisition. Pergamon Press Inc., 203 p. Available at: http://www.sdkrashen.com/ content/books/principles and practice.pdf/(accessed 6 March 2018). The name of the screen. [in English].

Стаття надійшла до редакції 12.03.2018

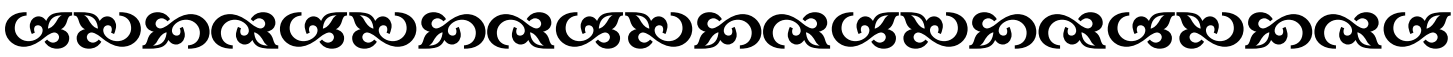

\author{
“Була б мета поставлена - а ланцюжок проб і помилоксам приведе до бажаного \\ результату..." \\ Харукі Муракамі \\ японський письменник і перекладач
}

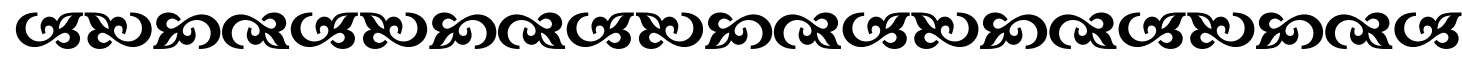

